\title{
Analysis of Microbiological Methods Applicable to Water Testing in Our Country
}

\section{Hazánkban vízvizsgálat céljára alkalmazható mikrobiológiai módszerek elemzése}

It is essential for our daily life to produce drinking water of the right quality and quantity. Water supply also includes the regular testing of drinking water to deliver impeccable water quality to consumers. 201/2001 (X. 25.) Government Decree on Quality Requirements for Drinking Water and Procedures for Monitoring contains the frequency of sampling and the designation of microorganisms to be detected in each test and the different standards on the basis of which the tests should be carried out. However, these methods are often time-consuming, it takes several days for the samples to produce results. However, there is a newer and more modern method to shorten the time.

This is particularly important in case of unexpected disasters, water pollution when it is extremely important to react quickly.

The aim of this article is to introduce (overview) the microbiological methods used for water testing in Hungary, describing the advantages and disadvantages of their application based on the author's own laboratory experience.

Keywords: water testing, microbiological test methods, water quality, test algorithm

A mindennapi élethez elengedhetetlen a megfelelő minőségű és mennyiségü ivóvíz előállítása. A vízellátás biztosításához hozzátartozik az ivóvíz rendszeres vizsgálata is, amelynek célja, hogy kifogástalan minőségü víz jusson el a fogyasztókhoz. Az ivóvíz minőségi követelményeiröl és az ellenőrzés rendjéről szóló 201/2001. (X. 25.) Korm. rendelet tartalmazza a mintavételek gyakoriságát, illetve az egyes vizsgálatok során a vízből kimutatandó mikroorganizmusok megnevezését és a különböző szabványokat, amelyek alapján a vizsgálatokat el kell végezni. Ezek a módszerek 
azonban többnyire időigényesek, több nap, míg eredményhez vezetnek. Létezik azonban újabb, korszerübb eljárás is, amellyel e vizsgálati idő lerövidíthető. Ez kiemelten fontos a váratlanul bekövetkező katasztrófahelyzetekben, vízszennyezések esetén, mikor rendkívül fontos a gyors reagálás.

A cikk elkészítésével célom volt, hogy bemutassam a hazánkban vízvizsgálat céljára alkalmazott mikrobiológiai módszereket, ismertetve alkalmazásuk előnyeit és hátrányait saját laboratóriumi vizsgálatok tapasztalataira támaszkodva.

Kulcsszavak: vízvizsgálat, mikrobiológiai vizsgálati módszerek, vízminőség, vizsgálati algoritmus

\section{Introduction}

Potable water is an essential element of life and daily activities. In Hungary, the quality requirements for potable water are strictly regulated by Hungarian and European legislation. It is a strategic public health task, under the control of the competent authorities, to provide drinking water of sufficient quality. In Hungary, the classification of potable water is dealt with in 201/2001 (X.25.) Government Decree (hereinafter: Government Decree) on drinking water quality requirements and inspection procedures.

The determination of water quality consists of professional sampling and physical, chemical, bacterial and biological tests on site and in laboratories.

Annex 1 to the Government Decree contains the microbiological and chemical test parameters for water and the associated limit values. On this basis, water meets the legal requirements if it does not contain a microorganism, parasite, chemical or physical substance that may endanger human health. In addition, there are so-called indicative water quality indicators, which have a primary control role. In such cases, exceeding the limit value does not pose an immediate public health hazard [1].

In the following, from the parameters of water quality, I will deal only with microbiological tests and methods, given the scope of the article. One of my goals is to introduce the microbiological methods used in Hungary to determine the microorganisms present in water. I consider it important to compare these methods and to present their advantages and disadvantages, because the method used in a given situation can play an important role. For example, in case of an unexpected event that may occur, it is essential to obtain results as soon as possible, while other factors, such as the need for equipment and cost effectiveness, play a role in the regular sampling of water from the water networks. Taking into account all these parameters I examined the applied methods.

Generally speaking, in Hungary, in accordance with the Government Decree, microbial cultivation methods are used for water quality purposes. However, there are also methods that reduce the incubation time so that results can be achieved faster. In the following, I introduce these methods in detail, and highlight the weaknesses and strengths of the methods using SWOT analysis. 


\section{Frequency of Water Tests and Parameters to Be Tested}

The frequency of sampling for water tests is determined by the Government Decree. The number of samples to be tested depends on the amount of drinking water supplied each day. The given waterworks takes an average of 4 samples per year in its area of operation, that is, in certain parts of the settlements at which a control test is performed. The purpose of this is to provide regular information on the organoleptic and microbiological quality of drinking water for human consumption, certain chemical water quality characteristics, changes in water quality and the efficiency of water treatment. The following parameters are checked during the test: colour, odour, taste, turbidity, $\mathrm{pH}$, conductivity, Escherichia coli, Coliform bacteria, colony count at $22^{\circ} \mathrm{C}$ and $37^{\circ} \mathrm{C}$, respectively. Methods for microbiological testing are contained in the Government Decree. In addition to the inspection, a detailed inspection is carried out once a year to determine whether the drinking water meets all the requirements of the Government Decree [1].

The parameters to be tested are listed in Table 1 and the standard by which the various tests are performed in an accredited water testing laboratory is also listed, i. e. the testing standards required by the regulations and the microbiological characteristics required therein. The Government Decree states that Escherichia coli, Enterococcus bacteria, Pseudomonas aeruginosa should not be present in the water. The Legionella limit is set out in EMMI Decree 49/2015 (XI. 6.) on Public Health Requirements for Media and Facilities Posing a Legionella Infection Risk (hereinafter: EMMI Decree) [2].

Table 1.

Microbiological water quality characteristics and standards

(Compilation of the author based on [1] [2])

\begin{tabular}{|c|c|c|}
\hline T est specific & Standard & Regulation \\
\hline Escherichia coli & MSZ EN ISO 9308-I & \multirow{5}{*}{$\begin{array}{l}\text { 20112001.(X.25.) Govermment } \\
\text { Decree }\end{array}$} \\
\hline Enterococci & MSZ EN ISO 7899-2 & \\
\hline Pseudomonas aeruginosa & MSZ EN ISO 16266 & \\
\hline Colony number at $22^{\circ} \mathrm{C}$ & MSZ EN ISO 6222 & \\
\hline Colony number at $37^{\circ} \mathrm{C}$ & MSZ EN ISO 6222 & \\
\hline Legionella & MSZ EN ISO 11731:20 17 & 49/2015.(XI.6.) EMMI Decree \\
\hline
\end{tabular}

\section{Microbiological Water Test Methods Used in Hungary}

Regular water quality tests are performed according to the parameters prescribed by the MSZ standards specified in the regulations. These standards describe in detail the assay procedure, the medium required for the detection of each microorganism, the amount of water needed for the sample and the incubation time after the result. 
In addition to the method in the Government Decree, there is another method for detecting microorganisms in water. These methods are described below.

\section{Breeding procedures}

In Hungary, the water testing laboratories apply microbiological methods for cultivation in accordance with the Government and EMMI regulations. As shown in Table 1, besides the microorganisms to be detected, there is a standard upon which the assays should be performed.

The plate count method is used to determine the colony count. The number of microorganisms is determined at two different temperatures, one at $22^{\circ} \mathrm{C}$ and the other at $37^{\circ} \mathrm{C}$. Plates are incubated for 72 hours at $22^{\circ} \mathrm{C}$ and 24 hours at $37^{\circ} \mathrm{C}$. The result is then reported using the battery count method.

For the detection of E. coli, Pseudomonas aeruginosa and Enterococci, the water sample is filtered through a standard pore size membrane filter, then the membrane filter is placed on the surface of a selective medium and incubated as prescribed. In all three cases, after 24-48 hours, colony counts are obtained.

For Legionella, it is most necessary to wait for results, as incubation of this microorganism takes up to 10 days.

Generally speaking, these methods include a relatively longer time, from 24 to 72 hours, but up to 10 days before incubating colonies.

\section{Other novel procedures}

In addition to the culture methods, there are other methods by which microorganisms in the water can be identified. In the following, I briefly describe how the detection of each microbe occurs.

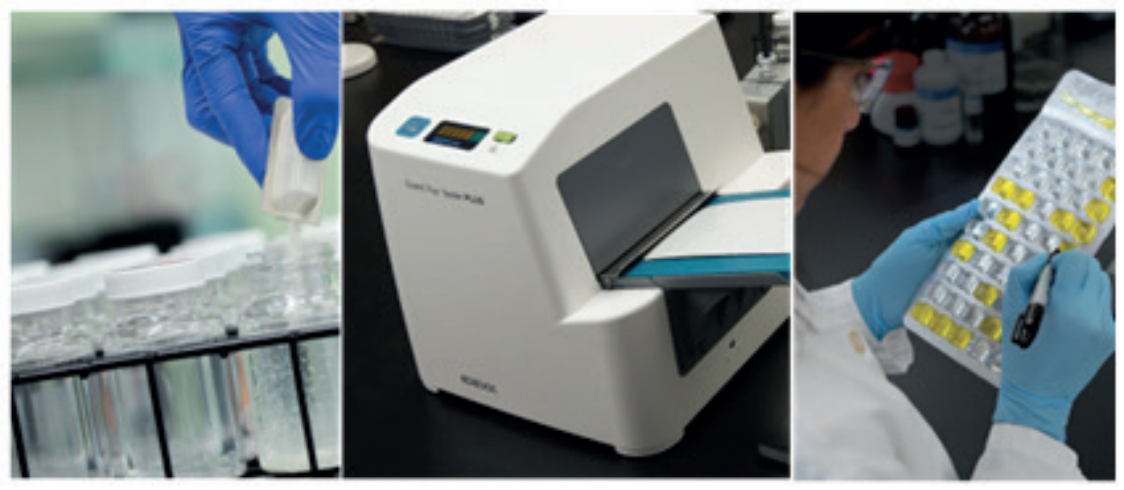

Figure 1.

Test method images [3] 
The principle of the methods is similar, the reagent is filled into the water sample and, after reconstitution, the Quanti-Tray is filled. The sample tray is then sealed and incubated at the appropriate temperature and time and the result is evaluated according to the method.

Detection of Coliform and E. coli is performed using Colilert 18 methods by pipetting a defined amount of the water sample into a bottle and then adding sterile water or Colilert reagent containing various salts, vitamins and sugars. All of this should be placed in a sachet, which is incubated at $36^{\circ} \mathrm{C}$ for 20 hours. Coliform positivity, as shown in Figure 1, is indicated by yellow cells.

For the detection of Coliform, the Colilert 18 method is based on the enzymatic degradation of ortho-Nitrophenyl- $\beta$-D-galactopyranoside (ONPG) by $\beta$-galactosidase. As a result of the enzyme activity, the sample changes from colourless to yellow. The procedure does not require UV light [4], [5], [6], [7].

However, for $\mathrm{E}$. coli, it is based on the enzymatic degradation of 4-methylumbelliferyl- $\beta$-D-glucuronide (MUG) by $\beta$-glucuronidase. As a result of the enzyme activity of the coliform positive yellow bubbles in the sample, the E. coli positive fluoresces blue under UV light [4]. Based on the number of coloured cells, the result can be read from a statistical table using the MPN method. Depending on the volume of the water sample, the results are given at 1, 10, 50 or $100 \mathrm{ml}$.

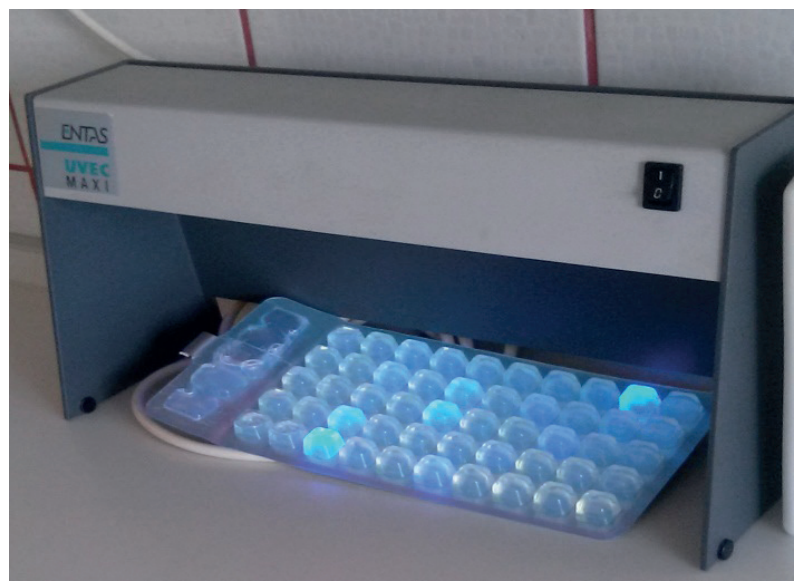

Figure 2 .

Detection of E. coli by the Colilert method [Made by the author.]

Detection of Pseudomonas aeruginosa was performed by the Pseudalert method, which operates on a similar principle to the Colilert mentioned above. Incubate the pouches at $38^{\circ} \mathrm{C}$ for 24 hours and then count the number of positive bubbles fluorescing blue under UV light. The result is also given by the MPN method [4].

The Enterolert-DW method is suitable for the determination of Enterococci. This is also based on the enzymatic degradation of ortho-Nitrophenyl- $\beta$-D-glucoside (ONPG) to glucoside. During incubation at $41^{\circ} \mathrm{C}$ for 24 hours, the colour of the positive 
sample changes from blue to green as a result of enzyme activity. The procedure does not require UV light.

For the detection of Legionella, a mixture of mineral salts and vitamins has also been developed and added to the water sample to give results within 7 days [8].

These methods are not yet widespread in Hungary, as they are quite expensive, but they have the great advantage over conventional breeding methods that they can produce results in a much shorter time. These procedures allow the results to be evaluated within 1 day, thereby gaining significant time compared to the culture methods.

A further advantage of the practical application of the new methods is that the treatment of microbiological contaminants and the disinfection of affected areas can be started sooner, thus reducing the further spread of infections [9], [10].

\section{Own Examinations}

In order to illustrate the microbiological methods used, I carried out laboratory tests aimed at examining the results obtained with each method. To do this, I took 5 samples from different locations, public wells and taps. From each sample I show the 5 parameters (colony number at $22^{\circ} \mathrm{C}$, colony number at $37^{\circ} \mathrm{C}$, E. coli, Enterococcus, Pseudomonas aeruginosa) contained in the Government Decree by the conventional breeding method as well as by the Colilert method. For each sample, I worked with 3 replicates, using the average of these results. The microorganisms to be detected were compared by sample, their results and their uncertainty are shown in Figures 3, 4 and 5. E. coli and Enterococcus were not detectable in either sample.

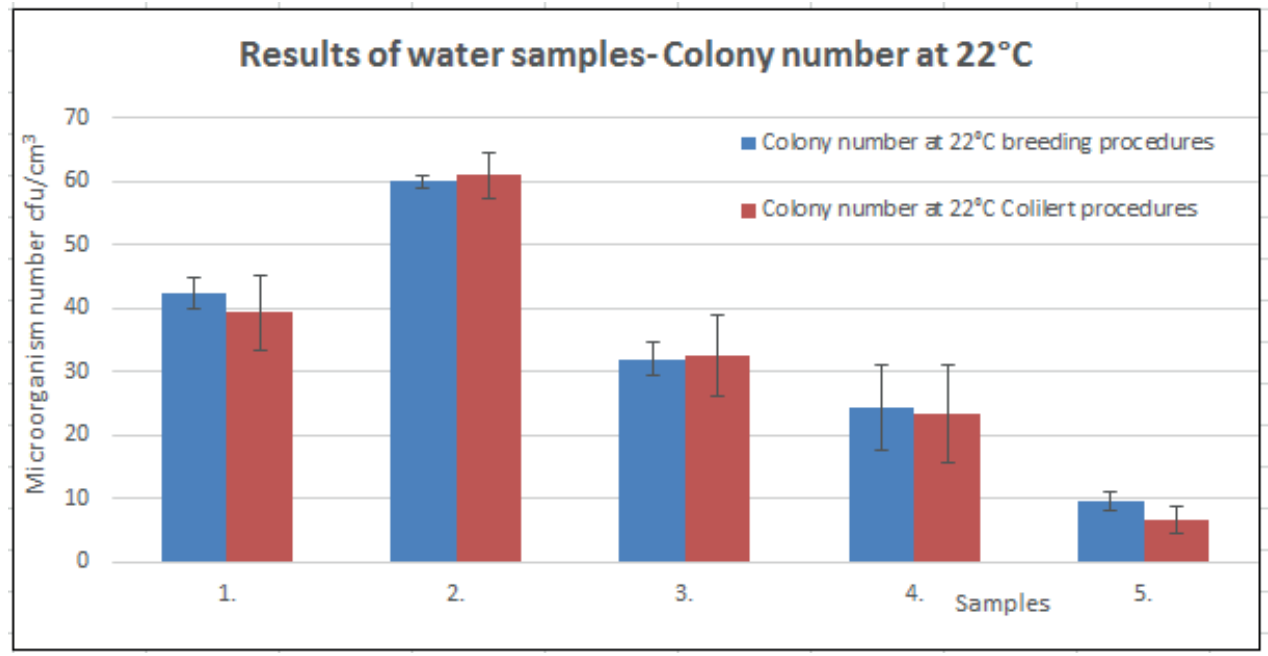

Figure 3

Determination of colony number at $22^{\circ} \mathrm{C}$ [Compiled by the author.] 


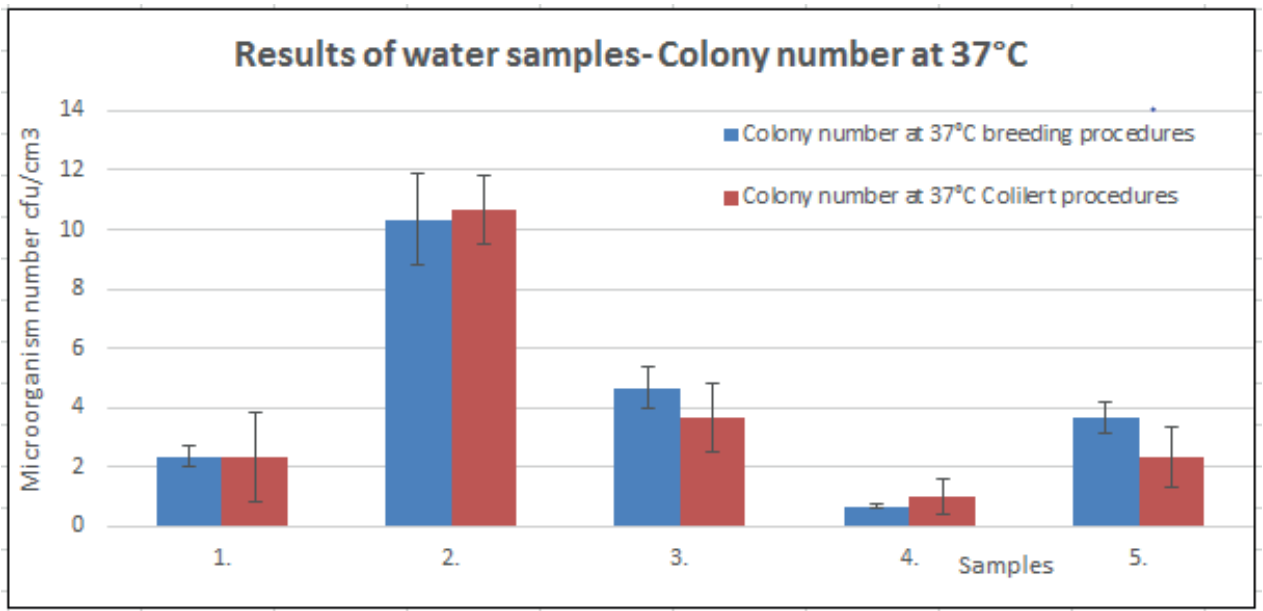

Figure 4.

Determination of colony number at $37^{\circ} \mathrm{C}$ [Compiled by the author.]

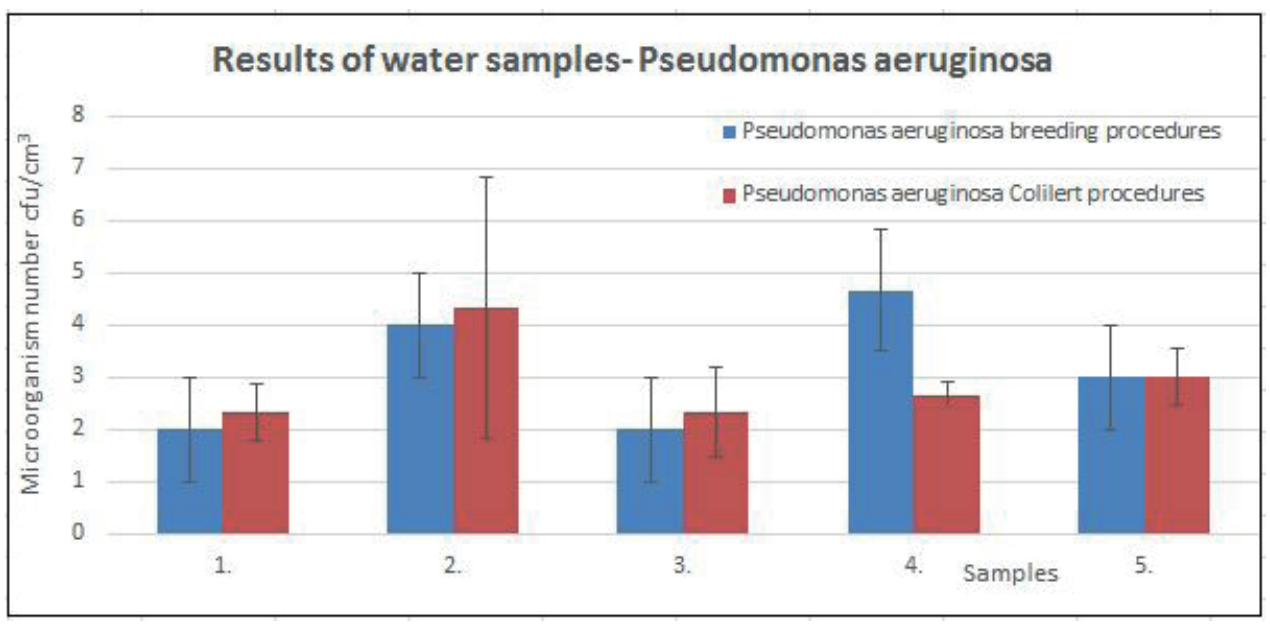

Figure 5.

Definition of Pseudomonas aeruginosa [Compiled by the author.]

The results of the measurements show that the data of the 2 methods correlate well, and similar results were obtained for each sample. 
Therefore, no decision can be made about the method to be chosen for the water test on this basis, so after further research, my goal was to show the advantages and disadvantages of the methods. Based on my own experience, I conducted a SWOT analysis to demonstrate the viability of a product through the following features:

- strengths

- weaknesses

- opportunities

- threats - dangers

Figure 6 shows the analysis of the culture method according to 4 parameters.

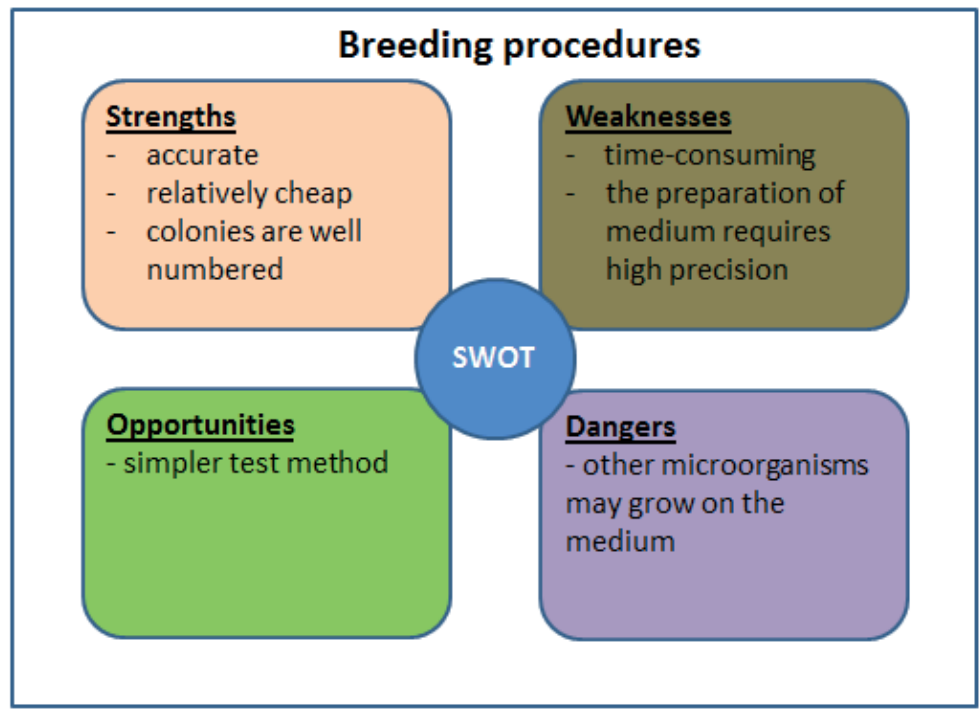

Figure 6.

Breeding procedures - SWOT analysis [Compiled by the author.]

As can be seen in Figure 6, one of the advantages of the culture methods is that they are relatively inexpensive thanks to the colony count method. However, it should also be noted that colonies grown on culture media may not originate from a microorganism and may be included in the results due to negligence in the calculation of colonies. As an option, the test method may be shortened. The medium also has to be weighed and made up of different ingredients, salts and minerals. In many cases, pre-weighed media, which only needs to be diluted with water, has been developed, but it is time-consuming to prepare as it can only be used for testing in petri dishes and incubated at a suitable temperature.

Figure 7 shows the parameters of the other novel procedure. 


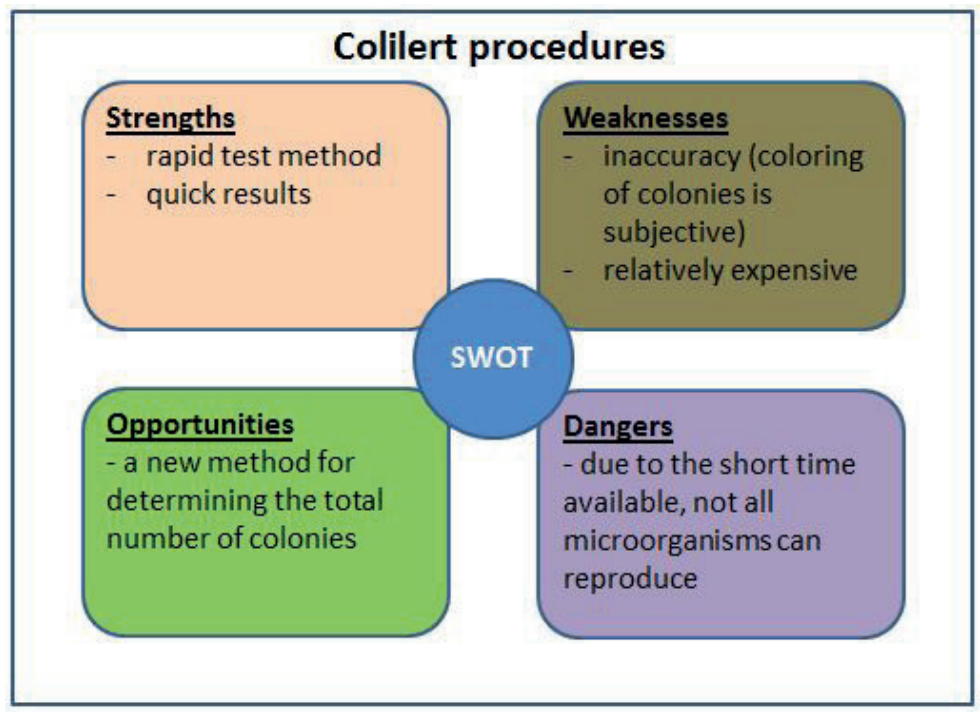

Figure 7.

Other procedures - SWOT analysis [Compiled by the author.]

The biggest advantage of other bagged methods is that the whole test method is quick, only adding a mixture of pre-purchased minerals and salts to the water sample, then pouring the mixture into the bags, sealing them and incubating at a suitable temperature. This gives results in a short time. After incubation, the results are based on the coloration of the pockets of the sachets, which in many cases is subjective, for example what is still yellow and what is not. The disadvantage is that this procedure and the equipment needed for it are relatively expensive. As a new option, another method could be developed that is capable of detecting all colony numbers, as this parameter is included in the Government Decree.

\section{Conclusions}

In my research, I have come to the conclusion that there are several factors to consider when choosing the right water test method. If an official water quality test is carried out in an accredited laboratory, then the regulations in force in Hungary must be followed, so the breeding procedures must be applied. In this case, after a relatively lengthy and tool-intensive sample preparation, the inoculation itself comes in, followed by an evaluation of the colonies after an incubation period of 1-2 days. If, on the other hand, a disaster or any unexpected incident occurs where drinking water is contaminated, then Colilert, Pseudalert, etc. should be used to achieve results in less time. All of this can increase the effectiveness of the damage elimination process and the faster disposal of the pollutant. The great advantage of these methods over 
the breeding methods is that they are obtained in a relatively short time and that the whole assay method is quick and simple.

Regular testing of potable water, including microbiological parameters, is essential to guarantee adequate drinking water supply for consumers. In this article, I have presented the features of other novel microbiological methods that are included in the legislation in force in Hungary and that are not yet in the current legislation. Laboratory test results show that there is no significant difference between the results of the two methods.

Therefore, when comparing the methods, I also applied SWOT analysis, which can be used to determine the advantages and disadvantages of each method based on the 4 parameters. I have described the factors that can act as obstacles in some cases. The knowledge of these is essential in order to apply the best method in the given situation.

With the results of my research I wanted to help the work of the experts dealing with the testing of potable water.

\section{References}

[1] 201/2001. (X.25.) Kormányrendelet az ivóvíz minőségi követelményeiről és az ellenörzés rendjéről [Government Decree on Quality Requirements for Drinking Water and Procedures for Monitoring].

[2] 49/2015. (XI. 6.) EMMI rendelet a Legionella által okozott fertőzési kockázatot jelentő közegekre, illetve létesítményekre vonatkozó közegészségügyi előírásokról [EMMI Decree on Public Health Requirements for Media and Facilities Posing a Legionella Infection Risk].

[3] "Colilert." [Online]. Available: www.arachem.com.my/index.php?cat=1173 [Accessed March 02, 2019].

[4] M. Reskóné Dr. Nagy, Sz. Dömötör, Gyors vizsgálatimódszereka víz mikrobiológiaiellenörzésében. Budapest: Hungalimentaria, 2015. [Online document]. Available: https:// docplayer.hu/282216-Gyors-vizsgalati-modszerek-a-viz-mikrobiologiai-ellenorzeseben.html [Accessed March 02, 2019].

[5] K. Takács, "Marcal folyó mikrobiális állapotának vizsgálata a vörösiszap katasztrófa tükrében," Hadmérnök, vol. 13, no. 3, Sept., pp. 290-305, 2018 [Online serial].

[6] D. Kapetanović, I. Vardić Smrzlić, D. Valić, and E. Teskeredžić, "Occurrence, characterization and antimicrobial susceptibility of Vibrio alginolyticus in the Eastern Adriatic Sea," Marine Pollution Bulletin, vol. 75, no. 1-2, Oct., pp. 46-52, 2013. DOI: https://doi.org/10.1016/j.marpolbul.2013.08.008

[7] J. M. Pisciotta, D. F. Rath, P. A. Stanek, D. M. Flanery, and V. J. Harwood, "Marine Bacteria Cause False-Positive Results in the Colilert-18 Rapid Identification Test for Escherichia coli in Florida waters," Applied and Environmental Microbiology, vol. 68, no. 2, Feb., pp. 539-544, 2002. DOI: https://doi.org/10.1128/AEM.68.2.539544.2002

[8] "Water." [Online]. Available: www.idexx.com/en/water/products/?cy=y_category _252\&ts=all [Accessed Feb. 04, 2019]. 
[9] R. Kuti, "Intézkedési program belvízvédekezési munkálatokhoz," Védelem, Tüzés Katasztrófavédelmi Szakkönyvtár, essay 67, pp. 1-12, 2007. [Online serial]. Available: www.vedelem.hu/letoltes/anyagok/67-intezkedesi-program-belvizvedekezeshez.pdf [Accessed Apr. 12, 2019].

[10] R. Kuti, "Mentesítési feladatok új dimenziói," Bolyai Szemle, vol. 16, no. 1, pp. 62-67, 2007. 